In this issue:

New Horizons for Academic

Libraries ...............22I

1978 Annual Conference ........226

Annual Report of the President .227

Highlights of ACRL Board of

Directors Meetings ........231

ACRL Officers for $1978 / 79 \quad \ldots .233$

Continuing Education-V . . . .235

AALS/Continuing Education

Committee Resolution . . . . 236

ACRL Chapters . ............237

News from the Field ..........238

People ..................249

Classified Advertising .......254

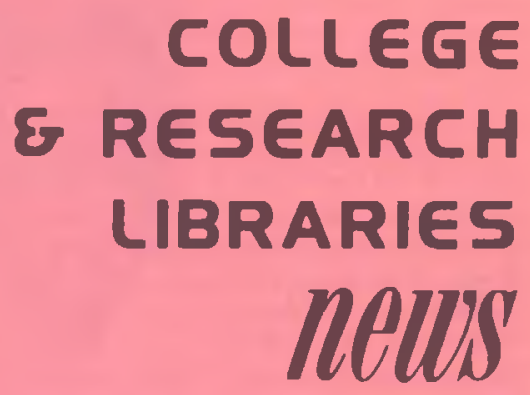

NO. 8 - SEPTEMBER 1978

\title{
New Horizons for Academic Libraries ACRL 1978 National Conference
}

The Association of College and Research Libraries observes its fortieth anniversary with its first national conference in Boston November 8-11 at the Sheraton-Boston Hotel

With its theme, "New Horizons for Academic Libraries," the conference focuses on the future prospects for academic and research librarianship in North America. Eight leaders in higher education and librarianship will give a broad overview of the problems and opportunities awaiting college, university, and research libraries.

At the opening session on Wednesday afternoon, November 8, Mary F. Berry, assistant secretary for education, Department of Health, Education and Welfare, will look at the future of higher education in the United States. At the second session that afternoon, Warren J. Haas, president of the Council on Library Resources, will speak on the management of academic libraries.

On Thursday morning, November 9, there will be a report from the National Enquiry into Scholarly Communication on the work of that project and present and future problems in scholarly communication. Morning session will conclude with an address by Joe B. Wyatt, vicepresident for administration, Harvard University, on the role of technology in our libraries. At an afternoon session on Thursday, Barbara Evans Markuson, executive director of the Indiana Cooperative Library Services Authority, wịll speak on cooperation and networking among academic and research libraries.

On Friday morning, November 10, Richard W. Boss, Information Systems Consultants, Inc., in Boston, will speak on programs and services in academic libraries, and he will be followed by Jay K. Lucker, library director at Massachusetts Institute of Technology, who will speak on library resources and bibliographic control. In the concluding theme address on Friday aftemoon, Millicent D. Abell, university librarian, University of California, San Diego, will speak of the changing role of the academic librarian.

During the first three days of the conference, there will also be seven periods during which a total of sixty-six contributed papers will be presented in a series of concurrent sessions. A list of

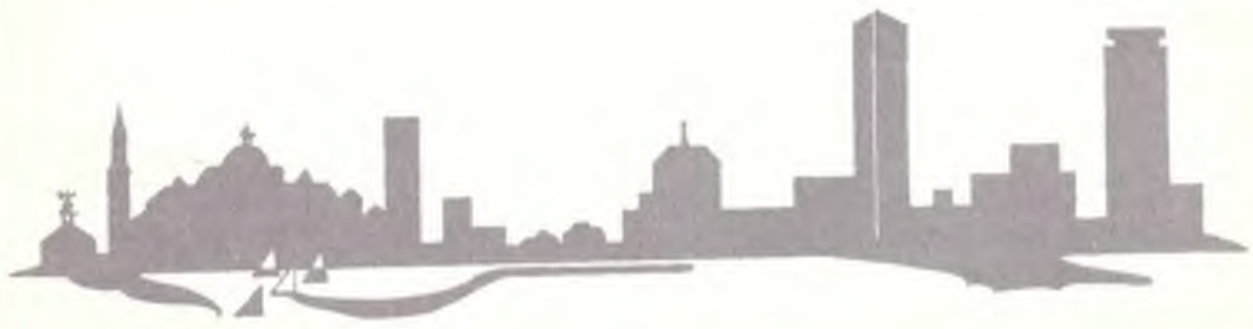

News issue (A) of College \& Research Libraries, vol. 39, no. 5 
Mary F. Berry, assistant secretary for education, Department of Health, Education and Welfare, to address Wednesday, November 8, session of ACRL conference.

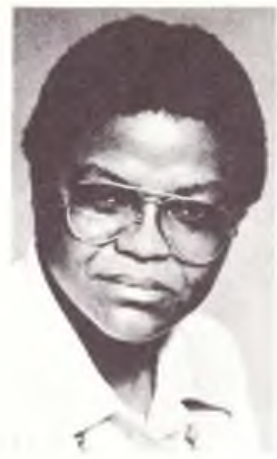

the authors and titles of these papers-and showing the broad range of subjects covered-appears below

In addition to the more than 115 commercial and professional exhibits in adjacent halls at the hotel, there will be a number of special functions-a reception at the Boston Public $\mathrm{Li}$ brary on Wednesday evening and at the Boston Museum of Fine Arts on Friday evening. A bonus of the conference is the exhibit at the museum, "Treasures of Early Irish Art, 1500 B.C. -1500 A.D., which includes the Book of Kells.

Conference participants will be able to participate in "A Boston Dinner" on Thursday evening, at which time Kurt Vonnegut will address the group.

The conference concludes on Saturday, November 11 , with a program of reports from the various national computer-based bibliographic networks. Conference participants will also be able to tour area libraries and will be given free admission to the Boston International Antiquarian Book Fair at the nearby Copley Plaza Hotel.

ACRL members have received registration information in the summer, and the July-August issue of American Libraries also includes registration forms. Further information is available from ACRL headquarters.

Space is limited for the conference, and early registration is urged!

\section{Conthibuted Papers acce PTE D for Presentation at the aCRL 1978 National Conference}

Martha J. Bailey, Purdue University. "Compensation Plans for Library Faculty Members."

Ken Balthaser, Indiana University-Purdue University at Fort Wayne. "Providing Knowledge and Client Links."

Joseph W. Barker, Virginia Polytechnic Institute and State University. "The Dutch-Door Circulation Desk."

Joseph A. Boissé, University of WisconsinParkside. "Dealing with the Fear of Change through the Self-Study Process."
John A. Bollier, Yale Divinity School. "Bibliographic Instruction in the Graduate/ Professional Theological School."

Ritvars Bregzis, University of Toronto. "The Technical Services Budget-1980 and Beyond."

Patricia Senn Breivik, Sangamon State University. "The Neglected Horizon; or, An Expanded Education Role for Academic Libraries."

C. Roger Davis, Smith College. "The Compleat Collection Developer."

Dennis W. Dickinson, University of Kentucky. "Subject Specialists in Academic Libraries: The Once and Future Dinosaurs."

Phyllis Dougherty, University of Tennessee Center for the Health Sciences. "Interdepartmental Swap-Off by the Buddy System: Report of a Staff Exchange Program."

Miriam A. Drake, Purdue University. "Management Control in Academic Libraries."

Anne C. Edmonds, Mount Holyoke College, and Willis E. Bridegam, Amherst College. "Perspectives on Cooperation: The Evaluation of a Consortium."

Richard Eggleton, University of North Carolina at Greensboro. "Academic Libraries, Participative Management, and Risky Shift."

Joanne R. Euster, Loyola University in New Orleans. "A Women's Profession in Academia: Problem and Proposal."

Glyn T. Evans and Mary H. Beilby, State University of New York. "Towards an Information System for Responsive Collection Development."

Raymond K. Fisher, University of Birmingham, England. "Academic Libraries and Part-Time Adult Students."

Barbara J. Ford and Yuri Nakata, University of II-

\footnotetext{
News items for inclusion in C\&RL News should be sent to John V. Crowley, Assistant Director of Libraries, Miine Library, State University College. Oneonta, NY 13820 . Display advertis Ing should be sent to Leona Swiech, Advertising Office, Amer can Library Association, 50 E. Huron Si. Chicago, IL 6051 Send classified ads to ACRL Production and circulation ma ers are handled by ALA Central Production Unit, at the above address.

News editor: John V Crowley. Assistant Director of Libraries Milne Library, State University College, Oneonta, NY 13820 telephone (607) 431-2725. Assistant news editor: Ellen L Huyler, Assistant Librarian. Acquisitions Department, Milne L. brasy. State University College, Oneonta, NY 13820. Editor Richard D Johnson, Milne Library, State University College. Oneonta. NY 13820. President. ACFL Eldred R Smith Exect tive Secretary, ACRL Julie A. Carroll Virgo.

College \& Research Libraries is published by the Association of College and Research Libraries, a division of the American Library Association, 17 times yearly -6 bimonthly journal is sues and 11 monthly (combining July-August) New5 issuesat 1201-05 Bluff St.. Fulton, MO 65251 Subscription, $\$ 25.00$ a year, or to members of the division. $\$ 12.50$. included in dues, Second-class postage paid at Fulton, Missouri 65251

(C) American Library Association 1978. All material in this journal subject to copyright by the American Library Association may be photocopied for the noncommercial purpose of scientific or educational advancement.
} 
linois at Chicago Circle. "Government Publications in Humanistic Research and Scholarship."

Selma V. Foster and Nancy C. Lufburrow, State University of New York, College at Potsdam. "Documents to the People in One Easy Step."

Beverlee A. French, University of California, San Diego. "The Fourth Generation: Research Libraries and Community Information."

Elizabeth J. Furlong and Karen L. Horny, Northwestern University. "The Future in Our Grasp: An On-Line Total Integrated System for Library Service."

Jeffrey J. Gardner, Association of Research Libraries. "CAP: A Project for the Analysis of the Collection Development Process in Large Academic Libraries."

Virginia Gillham and Margaret Beckman, University of Guelph. "Individual Autonomy and Successful Networking: A Canadian Experience."

Barbara B. Gordon, University of Washington. "The University of Washington's Participation in PACFORNET as a Contractor."

Jean L. Graef, CL Systems, Inc. "Interfacing Independent Automated Library Systems: A Sampling of Existing Attempts"

Jean L. Graef, CL Systems, Inc., and Larry Greenwood, University of Kentucky. “Marketing Library Services: A Case Study in Providing Bibliographic Instruction in an Academic Library."

Barbara Haber, Radcliffe College. "Women's Studies Resources for College and Research Libraries."

Michael John Haeuser, L.infield College. "Curriculum Reform: A Role for Librarians."

Edmund G. Hamann, Suffolk University. "Access to Information: A Reconsideration of the Service Goals of a Small Urban College Library."

Arthur T. Hamlin, Temple University, "A Backward Glance into the Future of University $\mathrm{Li}$ brary Support."

Gail A. Herndon and Noelle Van Pulis, Ohio State University. "The On-Line Library: Problems and Prospects for User Education."

Leila M. Hover, Suffern, New York. "The Independent Learner and the Academic Library: Access and Impact."

William J. Hubbard, Virginia Polytechnic Institute and State University. "Development and Administration of a Large Off-Campus Shelving Facility."

Edward R. Johnson, Pennsylvania State University, and Richard D. Hershcopf, Colorado State University. "The Undergraduate Library and the Subject-Divisional Plan: Problems and Prospects."

K. Suzanne Johnson and Joel S, Rutstein, Colorado State University. "The Politics of Book Fund Allocation: A Case Study."

Soon D. Kim and Mary T. Kim, Ohio State University. "Academic Library Research: A Twenty Year Perspective."
Thomas G. Kirk, Earlham College. "CourseRelated Library and Literature Use Instruction: An Attempt to Develop Model Programs."

Richard G. Landon, University of Toronto. "Rare Book and Special Collections Libraries: Horizontal Consolidation."

Anne Grodzins Lipow, University of California, Berkeley. "Teaching the Faculty to Use the Library: A Successful Program of In-Depth Seminars for University of California, Berkeley, Faculty."

I. T. Littleton, North Carolina State University. "State Systems of Higher Education and Libraries."

Richard Lyders, Diane Eckels, and Maurice C. Leatherbury, Houston Academy of Medicine. "Cost Allocation and Cost Generation."

Christina Wolcott McCawley, West Chester State College, and Scott Bruntjen, Shippensburg State College. "Librarians as Risk Takers: Design for Self Measurement."

Charles Martell, University of California, Berkeley. "Erasing the Past: Technological Shifts and Organizational Renewal."

Robert J. Merikangas, University of Maryland at College Park. "The Academic Reference Librarian: Roles and Development."

Susan L. Miller, Ohio State University. "The Evolution of an On-Line Catalog."

Glenn W. Offermann, Concordia College. "Participants' View of an Academic Library Consortium."

Diane C. Parker and Eric J. Carpenter, State University of New York at Buffalo. "A ZeroBase Budget Approach to Staff Justification for a Combined Reference and Collection Development Department."

Edwin D. Posey and Kathleen McCullough, Purdue University. "Approval Plans One Year Later: The Purdue Experience with Separate School Plans."

Jean M. Ray, Southern Illinois University at Carbondale. "The Future Role of the Academic Librarian, as Viewed Through a Perspective of Forty Years."

Jutta R. Reed, Massachusetts Institute of Technology. "Collection Analysis Project in the MIT Libraries."

Marion T. Reid, Anna H. Perrault, and Jane P. Kleiner, Louisiana State University. "The Role

\section{Addition to Endorsement List}

The State University of New York Librarians Association (SUNYLA) voted to endorse the ACRL. "Joint Statement on Faculty Status of College and University Librarians" at its council meeting of April 5, 1974. 
of the Academic Librarian in Library Governance."

Ralph E. Russell, Georgia State University "Growing Pains: An Administrator's Viewpoint on Drafting Library Faculty Bylaws."

C. James Schmidt, State University of New York at Albany. "Faculty Status in Academic Libraries: Retrospect and Prospect."

Damaris Ann Schmitt, St. Louis Community College at Meramec. "Prospects of Community College Librarianship."

Ward Shaw, Patricia B. Culkin, and Thomas E. Drabek, University of Denver. "The Query Analysis System: A Progress Report."

George J. Soete, Arizona State University. "The Collection Analysis Project at Arizona State University Library: An Exercise in Staff Development."

Aline Soules, University of Windsor. "OffCampus Library Services: Those Inbetween Years."

Sandra Spurlock and Ellen Yen, Massachusetts Institute of Technology. "Applications of an Operations Research Model to the Study of Book Use in a University Library: Implications for Library Management."

T. Philip Tompkins and Gary D. Byrd, University of Missouri-Kansas City. "The Urban Uni- versity Library: Effectiveness Models for 1989."

John Mark Tucker, Wabash College. "The Origins of Bibliographic Instruction in Academic Libraries, 1876-1914."

David B. Walch, State University of New York, College at Buffalo. "Budgeting for Non-Print Media in Academic Libraries.

Herbert S. White, Indiana University. "Budgetary Priorities in the Administration of Large Academic Libraries."

Stephen Wiberley, University of Illinois at Chicago Circle. "Sources for the Humanities: Measuring Use and Meeting Needs."

Billy R. Wilkinson, University of Illinois at Chicago Circle. "The Plethora of Personnel Systems in Academic Libraries: A Phenomenon of the 1970s."

Charles Willard, Princeton Theological Seminary. "Microforms: Changing the Conceptual Polarity from Negative to Positive."

Elizabeth J. Yeates and Laurie E. Stackpole, National Oceanic and Atmospheric Administration. "Managing for Results-A Case Study in Coalition Building."

John R. Yelverton, Georgia State University. "Win Some, Lose Some; Writing Bylaws for an Academic Library."

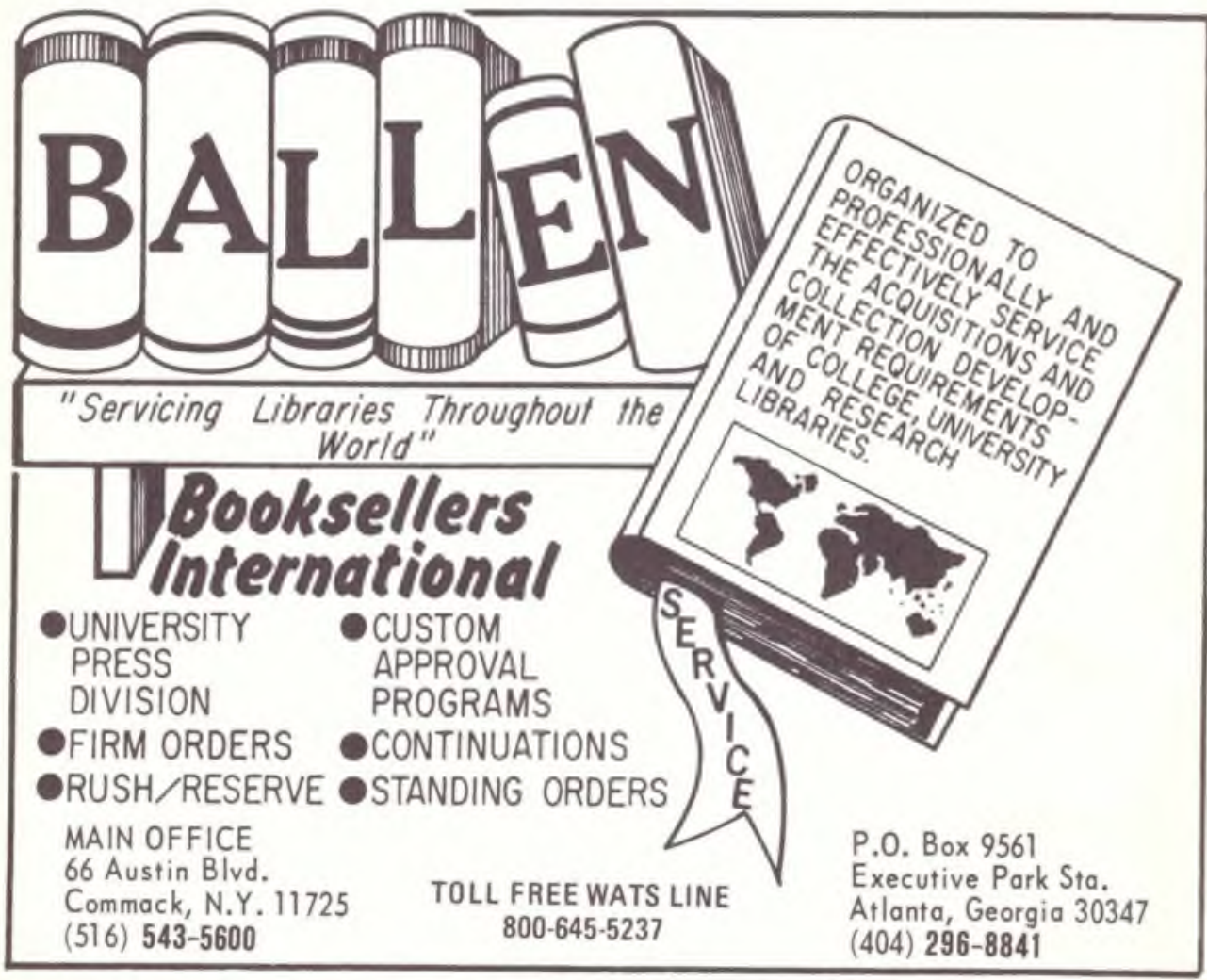




\section{New Horizons for Academic Libraries ACRL 1978 National Conference \\ November 8-11, 1978 \\ Sheraton-Boston Hotel \\ Boston, MA 02199}

\section{Pre-Registration Information}

Pre-Registration. A Pre-Registration Form is included here. Pre-Registration forms must be received no later than October 9 . Forms received after that date will be returned. On-site registration will be an additional $\$ 10$.

Payments. Checks should be made payable to the Association of College and Research Libraries or ACRL. Payments and registration forms are to be mailed to ACRL, $50 \mathrm{E}$. Huron St., Chicago, IL 60611. Your canceled check is your receipt; no receipts will be issued.

Refunds. Requests for refunded registration fees must be received in writing by the ACRL headquarters by October 23,1978 . A $\$ 5$ service charge will be deducted from such refunds. Requests for refunds after October 23, 1978, will not be honored.

For further information see p.410 of the July/ August 1978 American Libraries.

For a full conference brochure write the ACRL office.

\section{INFORMation for HOTEl. REgistration}

Room reservations will be assigned on a priority basis provided they are received 3 weeks prior to November 8, 1978. A first night's deposit for each room is required at least 10 days before arrival. It is refundable until 3 days before arrival date.

\section{ACRL 1978 NATIONAL CONFERENCE November 8-11, 1978 SHERATON-BOSTON HOTEL REGISTRATION FORM}

$\begin{array}{lc}\text { Name } & \text { No. in Party } \\ \text { Address } & \text { ZIP } \\ \text { Arrival Date } & \text { Time } \\ \text { Departure Date } & \text { Time }\end{array}$

Please circle rate and type of room required:

Single: $\$ 30$ (economy) $\$ 38 \$ 41 \$ 44 \$ 50$

Double: $\$ 50 \$ 51 \$ 54 \$ 60$ Twin: $\$ 51$

Triple: $\$ 54$ Quad: $\$ 60$

1-Bedroom Suite: $\$ 70 \$ 110 \$ 115 \$ 120$

2-Bedroom Suite: $\$ 140 \$ 165$

Mass. Room Tax 5.7\%

Please read Information for Hotel Registration (above) and send this form to: SheratonBoston Hotel, 39 Dalton St., Boston, MA 02199 .
PRE-REGISTRATION FORM ACRL 1978 NATIONAL CONFERENCE Sheraton-Boston Hotel November 8-11, 1978

\section{PLEASE TYPE OR PRINT}

Name

Affiliation

Street Address

City __ State ZIP

CONFERENCE PRE-REGISTRATION FEES

\begin{tabular}{|c|c|c|c|}
\hline & $\begin{array}{c}\text { Full } \\
\text { Comference }\end{array}$ & $\begin{array}{l}\text { Single } \\
\text { Day }\end{array}$ & Amsunt \\
\hline $\begin{array}{l}\text { ALA/ACRL Personal } \\
\text { Member }\end{array}$ & $\$ 35$ & $\$ 15$ & \\
\hline Student ALA Member & $\$ 20$ & $\$ 10$ & \\
\hline Non-ALA/ACRL & & $\$ 20$ & \\
\hline Exhibitor & FREE & FREE & \\
\hline Accompanying Person & $\$ 5$ & & \\
\hline $\begin{array}{l}\text { ACRL "Boston Dinner" } \\
\text { at } \$ 14 \text { per ticket } \\
\text { (not included in } \\
\text { registration) }\end{array}$ & & & \\
\hline
\end{tabular}

\section{ACRL MEMBERSHIP DUES 1979}

Renewal ALA/ACRL

New Member ALA/ACRL $\$ 50$

(Same Registration $\$ 50$

Fee as Members)

Already ALA member; please add ACRL

Student Member

Non-U.S. New

Member ALAACRL

\section{GRAND TOTAL}

\section{Please Indicate}

I plan to use the ACRL Placement Service at the meeting.

Please send me:

Employer's registration form(s). At one form per opening, I need _ number of forms.

Applicant's registration form.

As a physically handicapped person, I have special needs. (Please explain)

Make check payable to ACRL and mail this form and payment before October 9 to:

Association of College and Research

Libraries

50 East Huron Street

Chicago, IL 6061I 